\title{
By What Is the Soul Nourished? On the Art of the Physician of Souls in Plato's Protagoras
}

\author{
Jens Kristian Larsen
}

Therapeia de dê panti pantos mia, tas oikeias hekastôi trophas kai kinêseis apodidonai. (Timaios, 90c6-7)

At the end of the private conversation Socrates has with Hippocrates before both of them walk over to the house of Callias, Socrates presents a rather curious image: the soul is like a vessel (angeion) which is filled with the doctrines one learns (314a3b4). The image is curious if one believes that knowledge or wisdom, according to Plato's Socrates, is something that cannot be passed on to others like wares or commodities, a view expressed in both the Symposium (175d3-7) and the Republic (518b8-d1; see Manuwald 2006, 74). ${ }^{1}$ In the Protagoras, however, Socrates claims that doctrines, or mathemata, that one learns from others, are like food and drink to the soul: they are the very stuff by which souls are nourished (313c8-9). Accordingly, one should take care that one does not end up consuming unsound doctrines that will prove harmful rather than beneficial to the soul. In particular, one should take great care if one intends to buy doctrines from a sophist, for the sophist is presumably, according to Socrates, like a merchant (emporos) or a hawker (kapêlos) selling food: just as hawkers and merchants praise all their wares equally regardless of their quality, it may be the case that the sophist, who praises all he sells, does not know whether his wares are beneficial or harmful (313d1-e2). In fact, as a rule, one knows which of the doctrines are actually nourishing and which are not if one happens to be a physician of the soul, Socrates claims - but if one is not, one might well be ignorant of this (313e2-3). Since Hippocrates is obviously no such expert, Socrates' suggestion that he is about to put his soul into grave danger (313al-2) is understandable.

\footnotetext{
${ }^{1}$ Manuwald suggests that Socrates, in characterizing the sophists as merchants dealing in doctrines or "Wissensgüter", bases his characterization on the sophists' conception of education rather than on his own.
}

J.K. Larsen $(\square)$

Lecturer at Folkeuniversitet, Aarhus, Denmark

e-mail: zoon_kl@yahoo.com 
Less understandable is that Socrates, who seems to deny that he himself possesses the expertise characteristic of a physician of the soul (see 314b4-6), is willing to accompany Hippocrates to the house of Callias. If it is so dangerous to entrust one's soul to a sophist (313a1-c3), and if neither Socrates nor Hippocrates possess the knowledge needed to evaluate the doctrines sold by Protagoras, why does Socrates allow Hippocrates to go? At first sight it appears that Socrates, as Patrick Coby puts it, "can offer no satisfactory reason to justify their visiting Protagoras" (Coby 1987, 31). Coby goes on to suggest that Socrates knows that Hippocrates will go to Protagoras in any case, so that Hippocrates will be better off if Socrates accompanies him there (Coby 1987, 32). But the suggestion, although it has its merits, is not entirely satisfactory. Hippocrates claims that he has come to Socrates because he needs Socrates to introduce him to Protagoras (310e2-5), and he would therefore not have gone to Protagoras had Socrates not been willing to accompany him. Another possible explanation could be that Socrates is being ironic, in so far as he in fact possesses the expertise of the physician of souls, a suggestion advanced by Bernd Manuwald $(2006,75)$. Being a physician of souls, we may think, he will be able to help Hippocrates decide whether the doctrines advanced by Protagoras are nourishing or not. His critical discussion with Protagoras will thus ensure that Hippocrates does not end up consuming any of Protagoras' doctrines. This suggestion also has its merits, but it faces a problem: Socrates does not speak with Hippocrates after he enters the house of Callias. In fact he almost seems to forget him. Furthermore, that Socrates is helping Hippocrates through his discussion with Protagoras seems to presuppose that Hippocrates is able to see the contradictions in Protagoras' teaching that Socrates points out. But even careful readers of the dialogue are not always sure what these contradictions are. A third explanation could be that Socrates is ironical when claiming that Protagoras and the doctrines he sells are so dangerous. There is some truth to this suggestion, or rather, what Socrates is claiming about the dangers of sophistry is more complex than often assumed. Still, as we shall see, through his discussion with Socrates Protagoras is revealed to be a dangerous acquaintance: Socrates' warning is not unfounded.

We thus seem faced with a problem that this paper undertakes to investigate: Why does Socrates accompany Hippocrates to meet Protagoras? The first possibility to be considered in this connection is that the very fact that Hippocrates wants to associate with Protagoras shows that Hippocrates is himself a potentially dangerous young man, perhaps no less dangerous than Protagoras. It will further be urged that Socrates demonstrates that he is a physician of souls through his conversation with both Hippocrates and Protagoras. By this is not meant that he proves able to cure them (as we shall see he may be said to start treating Hippocrates), but rather that he proves able to assess or reveal their "psychic" fitness, to reveal whether they are healthy or not. A final point will be that what Socrates makes manifest about the condition of the soul of Hippocrates does not correlate with what Socrates reveals about the soul of Protagoras: what Hippocrates desires is not what Protagoras offers for sale. Perhaps it may even be the case that Socrates, by exposing what it is Protagoras sells, is able to show Hippocrates that Protagoras' wares are poisonous 
precisely because Hippocrates desires something that Protagoras is not able to give him: the honor that may be the aim of political ambition.

\section{Socrates Probes Hippocrates}

Early in the morning, as Socrates explains to an unnamed companion, Hippocrates, a young man acquainted with Socrates, called as he was lying in his bed. He did this with a view to having Socrates introduce him to Protagoras. For Protagoras, according to Hippocrates, is wise, and Hippocrates would like Protagoras to make him wise as well (310d7-8). More precisely, what Hippocrates has heard about Protagoras - for he has never met him himself - is that he is "exceedingly wise at speaking" (sophôtaton ... legein) (310e6). It is in order that he may learn this wisdom that he urges Socrates to accompany him to meet Protagoras.

Hippocrates is young, highly spirited and accustomed to rushing about in search of things he wants (See Coby 1987, 25-27): this is clear from the fact that he more or less storms into Socrates' bedroom in the early hours just before dawn (310a7b3), from his impulse to go to Socrates immediately once he has heard that Protagoras is in town, even though it is very late in the evening (310c5-d2), and also from the abrupt way he states his bidding to Socrates, which culminates in a heartfelt entreaty - Why don't we walk over to him! - followed by a hortatory appeal let's go! (310e2-311a2). In an aside to the unnamed companion Socrates also claims a previous familiarity with the manliness (andreia) and excitement (ptoiêsis) manifest in Hippocrates' fervent desire to visit Protagoras. Finally, when Socrates asks Hippocrates whether Protagoras has wronged (adikein) him, a suggestion Hippocrates jokingly accepts, Hippocrates explains that Protagoras wrongs him by alone being wise and by not rendering (poiein) Hippocrates wise as well (311d3-6). This suggests both that Hippocrates understands wisdom as something that can be imparted to one person by another, and that he regards it as something to which he has a rightful claim of some kind. It is perhaps not too much to say that Hippocrates is apt to remind us of the man dominated by thymos or spiritedness depicted in Book 8 of the Republic. All the same, Socrates convinces Hippocrates that they cannot go at once to Callias' house, where Protagoras resides, since it is early. Instead, he suggests, they should pass the time walking around in the courtyard until the sun comes up.

Apparently, Socrates is not entirely frank with Hippocrates. Behind his suggestion that they should wait some time before visiting Protagoras we find another motivation, a motivation Socrates explains to the unnamed companion and thereby also to us, but not to Hippocrates: Socrates wants to examine (diaskopein) Hippocrates by testing (apopeirasthai) his strength or resolve (rhômê) (311b1-2). He does so by questioning him about his intended visit to the great sophist. Later on, Socrates suggests that he is questioning Protagoras in order to see how he stands towards knowledge in a manner parallel to the way someone who, wishing to 
examine (skopein) the health or another bodily function of another man, might ask that person to uncover his chest or back (352a1-b2). ${ }^{2}$

This motif of inspecting or examining a man with a view to assessing the condition or "fitness" of his soul, which in the passages just mentioned is explicitly connected with Socrates' activity of questioning, seems to be echoed in the very first questions Socrates poses Hippocrates in order to examine him. ${ }^{3}$ Socrates wants to know whether Hippocrates has understood to whom he is going and what he will become, now that he has decided to seek out Protagoras. In order to spell out what he means by posing the question, he asks Hippocrates what he would answer were he asked the same question prior to going, not to Protagoras, but rather to his namesake Hippocrates of Cos, the famous physician (311b5-c1). Socrates then repeats the question, now about two sculptors, Polycleitus and Pheidias (311c5-8). As a rule of thumb, one can assume that Plato's Socrates chooses his examples with care: in addition to illustrating how one should understand the type of question he is asking, the examples given are often meant to illuminate certain aspects of the subject matter Socrates is inquiring into. We are therefore entitled to wonder whether Socrates sees a parallel, real or feigned, between the wisdom possessed by Protagoras and that of the physician, on the one hand, or that of the sculptors, on the other.

Although it would be worthwhile to examine what both examples may imply about Protagoras' wisdom, we shall limit ourselves to looking at one of them, the physician. Is there a connection between sophistry, or the wisdom of Protagoras, and medicine understood broadly as a craft directed at promoting, securing and restoring bodily health? Can a goal of sophistry be described as making the soul more "fit" or restoring "health" to it? As becomes clear at the end of the dialogue Protagoras is familiar enough with Socrates to have spoken about him often to others (cf. 361e1-5) and this may suggest that Socrates is no less familiar with Protagoras and his understanding of sophistry; maybe this familiarity informs Socrates choice of example at the beginning of the dialogue.

That this may be the case is further suggested by the fact that Socrates himself, in the discussion about pleasure and the good later in the dialogue (357e2-4), says that all the sophists present in Callias' house claim to be physicians able to cure ignorance (amathia). And Protagoras, when explaining in his display speech that almost everyone can acquire virtue, in the mythical part of the speech claims that anyone unable to partake in a sense of shame (aidôs) and justice (dikê) should be put to death because he is like a plague (nosos) in a city (322d5-6). This claim is repeated in the argumentative part of the speech where Protagoras states that such a man is incurable (aniatos; 325a7). Protagoras thereby implicitly likens education in

${ }^{2}$ See Lampert $(2013,108-9)$ who suggests that Socrates is "Ic]asting himself as a doctor"; this claim is too strong to be supported by the text in itself, however, since it need not be a doctor who inspects someone else's body. It is safer to say that Socrates' depicts his examination of the mind of Protagoras as analogous to the way someone might examine the bodily health or other functions of someone else by inspecting specifically his body.

${ }^{3}$ The metaphors of medical examination as philosophical inquiry and philosophy as medicine are found in many Platonic dialogues. An interesting discussion can be found in Moes (2000, 32-46). Moes does not discuss the Protagoras in any detail, though. 
virtue - where education should be understood in the widest sense - to medical treatment. We may note that Protagoras likewise compares his own educative efforts to the doctor's treatment in the Theaetetus (167a3-6): as the doctor uses medicine to improve the condition of his patients, the sophist uses logoi. ${ }^{4}$ In both dialogues, it seems, Plato depicts Protagoras in a way suggesting that he understands sophistry as being somehow analogous to the physician's knowledge. Whether Socrates ultimately agrees with this view is another question.

When Socrates likens Protagoras' wisdom to that of a physician he asks what Hippocrates would become if he went to a physician intending to pay him wages on his own behalf (argurion telein hyper sautou misthon ekeinôi). Hippocrates claims it would be in order to become a physician (311b5-c4). He apparently does not consider the other alternative, that he might go to the physician in order to get a health examination, to receive advice how to live or to be cured from any ailments from which he might be suffering. ${ }^{5}$ This is perhaps no surprise given that Hippocrates wishes to go to Protagoras in order to learn something: he assumes that Protagoras possesses a certain wisdom that he will be able to pass on to others for wages. Still, one could go to a physician and pay him wages in order to learn something, for instance how to live a healthy life, without thereby wishing to become a physician oneself.

Hippocrates' understanding of the reason people go to wise people to learn from them immediately leads him into difficulty. If one goes to such people in order to learn their wisdom as something analogous to an art, as Hippocrates' response to Socrates' examples suggests, going to Protagoras would turn one into a practitioner of Protagoras' wisdom, that is, a sophist. But Hippocrates emphatically does not want to become a sophist (312a6-8). He is therefore happy when Socrates suggests a new way of thinking about Protagoras and his wisdom: perhaps Protagoras is like a writing teacher, a music teacher or a gymnastic teacher (312b1-2), that is, someone able to teach subjects that are part of a general education (epi paideiai, 312b34). This, Hippocrates now claims, is exactly the kind of learning or instruction (mathêsis) he believes he will get from Protagoras (312b5-6). We may gather that Hippocrates wishes to be introduced to Protagoras in order to become wise, not in order to become what Protagoras is, but, we may assume, in order to enjoy the power Protagoras' wisdom brings. We should note that this does not preclude Hippocrates' believing that what Protagoras has to offer is something like a craft he can teach, since writing and gymnastics are certainly crafts or arts. It need mean only that he accepts that it is not a craft one acquires in order to become a professional craftsman. ${ }^{6}$ As Socrates suggests, Hippocrates wishes to learn only what is becoming for a free man (312b4), he certainly has no plan to become a wage-earner.

\footnotetext{
${ }^{4}$ One may compare what Protagoras states here with Gorgias' Encomium of Helen, 8-10. See Roochnik (1996, 71-74) for a discussion of this.

${ }^{5}$ This is pointed out by Mr. Reinken in Strauss (1971, lecture 4, 22).

${ }^{6}$ This is emphasized in Adkins (1973).
} 
We now know that Hippocrates hopes to gain instruction relevant to a general education from Protagoras, and, more precisely, that he hopes to become good at speaking. But Socrates doubts that Hippocrates even knows what a sophist is. If he does not know this, Socrates goes on to warn him, he has in mind to hand over his soul to the service, caretaking, cultivation or medical service - the Greek verb is therapeuein - of someone whose professional credentials he does not understand; this means that he does not know whether this "handing over" of the soul is a good thing or not (312c1-4). Again we see Socrates suggesting that Protagoras, should he be willing to teach Hippocrates his wisdom, will treat or take care of the soul of Hippocrates in a manner like the way a physician or trainer might attend to or take care of bodies, even if he also implies that he may be a fraud.

Hippocrates responds by saying that he on his part thinks he knows what a sophist is, namely someone knowledgeable about wise things, since this, according to Hippocrates, is what the name "sophist" implies (312c5-8). ${ }^{7}$ But this answer does not satisfy Socrates. Painters and builders also understand "wise things", he explains, and therefore Hippocrates needs to specify the kind of work or activity (ergasia) about which the sophist is knowledgeable, just as he would be able to say that the painter understands how to make likenesses (312c9-d5). Hippocrates therefore states that the sophist makes (poiein) people clever at speaking (deinos legein, 312d6-7).

This brings Hippocrates' reason for going to Protagoras into full view: Hippocrates wishes to go to Protagoras because he thinks that Protagoras' professional activity is to produce competent speakers, which to Hippocrates seems to mean politically competent speakers. For, as Socrates later points out, Hippocrates appears to him to desire to become distinguished or highly regarded (ellogimos) in the city $(316 \mathrm{c} 1-2),{ }^{8}$ and it is presumably with this aim in view he wishes to learn to become clever at speaking from Protagoras.

Before we go on, we should take a moment to consider how we are to understand the relation between the sophist and his pupils. Hippocrates seems to believe that a sophist teaches his pupils to speak in a way analogous to the way other craftsmen teach their pupils their respective crafts, as can be seen from his responses to Socrates' various analogies. What does this belief imply about the effect of the sophist's teaching? In general we may claim that, in teaching a craft, a craftsman passes on his craft to a pupil, and the result of this teaching will be that the successful pupil will acquire the wisdom or virtue of the teacher and accordingly be able to produce or do the same things as the teacher: thus the painter teaches the pupil how to paint, the sculptor how to make sculptures, the writing teacher how to write. If

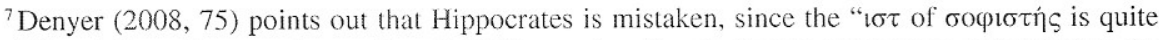
different from the $\iota \sigma \tau$ of $\varepsilon \pi \iota \tau \tau \dot{\eta} \mu \omega$ ". Still, one should note that Socrates does not object to the etymology here, and perhaps also that Theaetetus seems to make a similar inference in the Sophist $221 \mathrm{c} 9-\mathrm{d} 6$ insofar as he claims that the name sophist implies that the sophist cannot be a layman, but must be thought of as possessing technê.

${ }^{8}$ It is a nice touch on Plato's part that he has Protagoras ending up (361e4-5) stating that he shouldn't be surprised if Socrates should become one of the men distinguished (ellogimoôn andrôn) for wisdom. 
sophistry is teaching how to speak, and if this instruction corresponds to the way crafts are taught, the primary concern of the sophist would be to make sure that his pupil acquires the wisdom that will enable him to produce good speeches. In all these cases, we may suggest, the mastery or virtue of the craft acquired would be attested to by the products or actions of the pupil. The quality of a painting immediately reveals the level of mastery acquired by an apprentice just as a clever speech immediately bears witness to the wisdom or competence of the pupil of the sophist. In order to evaluate whether the sophist is successful as a teacher, one has merely to consider whether his pupils are able to speak well or cleverly.

However, if we consider Socrates' previous analogy between sophist and physician, we may suggest another way of looking at the sophist's relation to his pupils. This way of seeing the relation is worth spelling out in some detail, no matter how ironical Socrates' suggested analogy may be, for it will have a bearing on the way we should understand Socrates' relation to Hippocrates. If the sophist is like a physician, his primary activity will consist in exercising his art on others, not in teaching it to others. If we follow the analogy further, this exercise would include an assessment of the psychic condition of the pupil, possibly his treatment, and finally advice how the pupil should live and train his soul after the "consultation"; but none of this would correspond to passing on the craft of the sophist to the pupil, just as the physician would not turn his patient into a physician even while he gave him a rudimentary understanding of the principles of bodily health enabling him to live a better life. That this is a more adequate way of understanding the relation between sophist and pupil than the one according to which the sophist is like a writing teacher seems somewhat confirmed by the fact that Socrates warns Hippocrates that he does not understand to whose care he is handing over his soul, and perhaps also by the fact that we are later told that only one of the men in Protagoras' entourage or "chorus", Antimoiros of Mende, follows him in order to learn his craft (315a3-6). Even if this remark is meant to indicate that the rest of the entourage stay with Protagoras for the sake of education (cf. 312b2-4), we seem entitled to infer that Antimoiros is the only one who is out to learn all the tricks of Protagoras' trade.

Let us now return to Socrates' cross-examination of Hippocrates. Given that Hippocrates claims that a sophist makes people clever at speaking, Socrates asks to know what it is that Hippocrates believes the sophist makes people able to speak cleverly about. Hippocrates vaguely suggests that this must be things about which the sophist makes his pupils knowledgeable, but when Socrates asks him what this is, he admits that he is no longer able to answer (312e5-8). Hippocrates, who would very much like to become a pupil of Protagoras, does not have anything to say when asked what he presumes Protagoras will teach him, except the ability to speak cleverly.

Hippocrates' problem with specifying what Protagoras teaches mirrors Gorgias' problems in the dialogue named after him. Like Hippocrates, Gorgias has trouble identifying a specific subject matter for the rhetoric that he teaches, and hence, according to Socrates at least, in identifying what type of craft rhetoric is, on the assumption that a craft must have an identifiable field of objects (cf. Gorg. 449c9-453a7). But there is a significant difference: Hippocrates is not himself a 
practitioner of the ability to speak cleverly or rhetorically. Furthermore Hippocrates has never even met Protagoras and he clearly does not understand what it is that Protagoras himself claims to teach, namely euboulia (cf. 318e5). All he knows is that everybody praises the man and says that he is most wise when it comes to speaking (cf. 310e3-6): accordingly he has probably not even considered the question whether clever speaking per se is identical with the virtue that Protagoras calls euboulia. It is, then, presumably the general rumor that Protagoras' wisdom is concerned with speaking that Hippocrates interprets to mean that Protagoras will be able to make others clever at speaking; alternatively Plato may mean to suggest that Hippocrates merely repeats what people in general thought the average sophist did. But Protagoras is not the average sophist and we have no right to assume without further ado that Protagoras teaches what Hippocrates believes he teaches. ${ }^{9}$ If Protagoras does not see euboulia as identical with an ability to speak cleverly, ${ }^{10}$ Hippocrates is mistaken about the character of his wisdom. We shall return to this point below.

Socrates now sums up what he has established so far through his examination: Hippocrates intends to hand over his soul to a sophist and pay him a great deal of money, without having discussed with anyone whether this is a good thing to do, even though he obviously does not know what a sophist is (313a1-c3). This summary finally makes Hippocrates listen: he admits that Socrates is stating how things are, and thus acknowledges his aporia. He thought he knew what sophistry is, but he now sees that he did not. Since this is a step towards becoming wiser according to what many take to be Socratic standards, a step that removes the false belief that one knows what one does not, ${ }^{11}$ which could be regarded as analogous to the doctor's purging of the patient's body before bringing it sustenance (cf. Soph. 230c47), Socrates may be said to have started tending to Hippocrates. ${ }^{12}$

But Socrates' bringing Hippocrates into aporia is perhaps only the first step in his tending to Hippocrates. For the fact that Hippocrates desires to go to Protagoras at all might imply that Hippocrates is potentially dangerous, not simply because he believes to know what he does not, what sophistry is, but also because he desires political power, apparently with little understanding of political matters. It seems to be Hippocrates' desire to learn to speak well or cleverly in order to become

${ }^{9}$ That it is Hippocrates, and not Protagoras, who claims that Protagoras teaches the art of speaking cleverly, is correctly emphasized by Stokes (1986, 186-191). Stokes identifies the ability to speak cleverly with rhetoric but it should be noted that the word "rhetoric" is itself never used in the Protagoras.

${ }^{10}$ In the Gorgias (463a8-465c), Socrates distinguishes sophistry from rhetoric, claiming that rhetoric and sophistry are both types of flattery, but that rhetoric is an imitation of corrective justice (punishment), the psychic equivalent of medicine, whereas sophistry is an imitation of lawgiving, the psychic equivalent of gymnastics. Hence rhetoric is like pastry cooking, whereas sophistry is like cosmetics. In the Theaetetus, Socrates, impersonating "Protagoras", in a similar manner draws a distinction between the sophist and rhetorician and suggests that sophistry is like private education (167c2-d2) comparable to the expertise of the physician (167a5-6).

${ }^{11}$ See Manuwald $(2006,73)$.

${ }^{12}$ See Friedländer $(1964,3)$. 
distinguished in the city that induces him to seek out Protagoras (cf. 316c1). But as he proves unable to specify in regard to what in particular he hopes to be able to speak cleverly, and since he does not think that Protagoras will teach him anything other than this ability, it seems that the wisdom he hopes to learn from Protagoras is but a means to an end: to come to be regarded as significant in a political sense. Indeed, the fact that Hippocrates thinks Protagoras will make him knowledgeable only about speaking suggests that Hippocrates does not imagine that he needs to acquire knowledge about political matters in order to become renowned in the polis. It seems that Hippocrates thinks that no specialized expertise regarding political matters exists, which is in accordance with what Socrates, at least, claims is the Athenian sentiment, according to which it is not teachable and hence not something possessed by experts in contrast to laymen (319a8-d7).

Socrates now goes on to suggest to Hippocrates that a sophist is "a kind of merchant or hawker of wares by which the soul is nourished" (313c5-6). Although this may seem a strange claim in the mouth of Socrates, we now see that it may be a response to Hippocrates' understanding of sophistry. Perhaps it is also meant as a provocation the purpose of which is to make the young man think. In any case, Hippocrates' response to this suggestion is the last of his comments Plato has Socrates report to his companion. Hippocrates' response is to ask, "But by what is the soul nourished, Socrates?" (313c5-8). Even if Socrates goes on to give Hippocrates a quick answer to this question - a soul is nourished by the things that one can learn (mathêmata) - Hippocrates' question should be heard as resonating through the rest of the dialogue. For this, presumably, is what young Hippocrates really needs to learn. Indeed, if the soul is nourished by what can be learned, Hippocrates needs to know what the learnable things that are healthy are and whether Protagoras possesses them. Hitherto, Hippocrates has not cared about either question. That Protagoras may in fact impart nothing by which a soul may be nourished, and that one needs a specialized competence in order to judge whether he does, is what Socrates points out to Hippocrates in his final warning before the two of them set out to meet Protagoras.

Socrates explains to Hippocrates that they should beware lest the sophist deceive them by praising his wares, just as merchants dealing in food for the body are wont to do. The latter, Socrates claims, do not know whether what they sell is useful or harmful to the body, but praise all of it, and those who buy their wares are likewise ignorant of this, unless they happen to be physicians or gymnastic trainers (313d14). In a similar manner, he goes on to suggest, the sophists praise all their wares, but some of them may be "ignorant whether the things they sell are useful or harmful for the soul" whereas those who buy the sophists' wares have no understanding of it either, "unless one should happen to be a physician of the soul" (313d6-e3). So, if Hippocrates is such a physician, he may safely buy wares from Protagoras or anyone else, but if he is not, he should watch out lest he damage his soul.

Two things should be noted here. First, the analogy between the expertise set over the quality of food for the body and the one set over food for the soul may suggest that there are two aspects of the expertise of the physician of souls, since both the physician and the gymnastic trainer are said to be able to evaluate food for the 
body, corresponding to only one competence when it comes to looking at food for the soul. This could suggest that the physician of souls will have knowledge analogous to that of a physician as well as to that of a physical trainer; these were closely related according to the ancient understanding of medicine. If Socrates intends to point to any difference between physician and gymnastic trainer it might be that the physician is more concerned with assessing whether the food is good or bad for the body when ill or recovering, while the gymnastic trainer considers whether the food will nourish a healthy body and make it stronger. We may in fact suggest that Socrates, in inspecting the soul of Hippocrates and assessing what type of question will help reveal its state of ignorance, has demonstrated his mastery of the "diagnostic" competence of the physician of souls. When he later starts to assess the quality of the goods Protagoras offers for sail, in order to make Hippocrates aware of the potential risk involved in buying these, he seems to exhibit the other aspect, which addresses the question what nourishes the soul and keeps it healthy.

Second, Socrates is not claiming that all sophists are ignorant of the quality of what they are selling. In contrast to the sellers of food for the body, who according to Socrates are all ignorant about their wares, Socrates only suggests that some of the sophists may be ignorant about what they teach. Even if this is probably an ironic understatement, it must be emphasized that Socrates is not issuing a general warning about sophistry as such but is specifically warning Hippocrates that he ought to make sure that he is able to evaluate the quality of what the sophists are selling since they may be ignorant about its quality. Connected herewith we should note that the main point of Socrates' warning is not to restrain Hippocrates from going to Protagoras. It is rather to make Hippocrates see the importance of the craft practiced by the hypothetical physician of the soul. If one had this craft one could easily discern which learnable things, which doctrines, are useful and which are harmful, and this would remove the danger that might be connected with talking to any sophist. The point is not so much that Hippocrates is in grave danger if he goes to a sophist but safe if he does not, the point is rather that he is in danger because he wishes to go to a sophist without knowing what is beneficial for the soul and what is not. Had he no wish to go to Protagoras, there would be no danger, and if he learns the craft of the physicians of souls, the potential dangers in his associating with a sophist disappear in any case.

These things should be kept in mind as we read the final section of Socrates' warning, which runs from $314 \mathrm{a} 1$ to $314 \mathrm{c} 2$. Here Socrates states that the danger of harming the soul when one buys doctrines from the sophist is far greater than the danger of harming the body when one buys food for the body. For bodily foodstuffs can be brought home in containers and examined with regard to their quality before one consumes them. But "psychic sustenance", what you learn (to mathêma), you cannot carry away in another container; it is necessary that, once you have paid and have taken what is learnable into your soul and learned it, you walk away either benefited or harmed (314b1-2).

Let us end the discussion of the section featuring Socrates talking with Hippocrates by considering what Socrates is claiming here. It is easy to assume that he is issuing a general warning against dangerous doctrines. If you listen to a 
sophist, you may be corrupted straight away, since doctrines affect your soul directly. In this case, Socrates could be regarded as arguing for strict censorship: young people should not be allowed to listen to sophists, since they corrupt people. But if this is what he is saying, we face the paradox pointed out at the beginning of the paper: why does Socrates let Hippocrates visit Protagoras? We should note, however, that what Socrates claims is that you necessarily walk away either harmed or benefited (anagkê apienai ê beblammenon ê ôphelmenon)

1. when you have paid (katatheis),

2. when you have accepted (labôn) and

3. when you have learned (mathôn) what is sold (314b1-2).

But whether the pupil takes and learns the lessons a teacher gives is something that does not solely depend on the teacher; it depends as much on the pupil, as any teacher will know. Others need only think of old Strepsiades in Aristophanes' Clouds. A pupil uninterested in, or incapable of learning, or one who is skeptical of what you are saying, will never simply absorb what you say as the truth. The ground in which the seeds of learning are to be sown must be fertile and well-prepared in order for the seeds to grow, as Socrates suggests elsewhere (Phaedrus 276b1-277a4). Hippocrates was surely fertile soil for Protagoras when he came to Socrates that morning, since he was already convinced that Protagoras was the wisest of all, all eager to learn how to speak cleverly. But we may assume that Socrates, through his cross-examination of Hippocrates, has made Hippocrates less likely to absorb what Protagoras says uncritically. With these considerations in mind, let us now look at what Protagoras in fact claims to be able to teach.

\section{The Mathêma of Protagoras}

Having entered the house of Callias, Socrates asks Protagoras, on behalf of Hippocrates and in front of both Hippias and Prodicus, what will be the outcome, or result, for Hippocrates if he associates with, or studies with Protagoras (318a1-4). Prior to asking this question Socrates has explained to Protagoras that he thinks Hippocrates intends to become distinguished in the city (316c1). So Protagoras knows why Hippocrates has come to him. In answer to the question what Hippocrates will gain by associating with him, Protagoras initially states that Hippocrates will become better each day. This echoes what he has said a little earlier, where he has suggested that he, like other sophists, persuades the young that "they'll be the best they can be through their association with him" (316c8-d2), and also that he, in contrast to other sophists, openly confesses to be an educator of human beings $(317 \mathrm{~b} 2-3)$. The question is what Protagoras means by education and by becoming as good as possible. In other words, at what does he make people better, in what does he educate them? This is exactly what Socrates, at 318b1-d4, bids Protagoras clarify. 
If Protagoras simply claimed to make people clever at speaking, as Hippocrates seemed to assume, we might expect that he would have difficulties in pinpointing his specific area of expertise - after all, this proved a problem for Hippocrates. But this is not what happens. When asked what he teaches, Protagoras answers professionally and to the point: Hippocrates will not learn what he is forced to learn by the other sophists, but only what he comes to learn (218d7-e4). Probably as a response to Hippocrates' reported wish to become distinguished in the city, Protagoras explains that what he teaches is good counsel or being well-advised, i.e. euboulia, concerning one's household, namely how it will be best managed, and concerning the affairs of the city, how one becomes most able to act and speak regarding these affairs (318e4-319a2). Euboulia is the mathêma that Protagoras offers for sale. When Socrates asks whether Protagoras means the political craft and whether he promises to render men good citizens (319a3-4), ${ }^{13}$ he affirms that this is so.

We note that, even while there may be a link between the ability to speak well or cleverly and being powerful concerning the affairs of the city, it is implausible that the ability to speak well should exhaust the meaning of euboulia. ${ }^{14}$ One hardly becomes able to act politically merely through the ability to speak, nor does one manage a household by such an ability alone. In fact, Protagoras never explicitly claims that this is the case, or that he teaches others the ability to speak cleverly. There is thus some irony in the fact that Protagoras seems to offer Hippocrates something else than what Hippocrates wants to learn, while claiming that Hippocrates will only learn what he has come to learn. In order to become distinguished in the city Hippocrates needs, according to Protagoras, to be well-advised in private and in public, rather than to be able speak cleverly, as Hippocrates apparently thought sufficient. From a purely formal perspective, Socrates can hardly have any objections. Indeed, what Protagoras claims to teach has a certain resemblance to the wisdom Socrates claims the political leaders of the ideal city described in the Republic must have, a wisdom that is also identified with euboulia (Rep. 428b4-d9, 500b8-d9, and 504e3-505b3). ${ }^{15}$

As soon becomes clear, however, Protagoras' assertion that he teaches euboulia raises important questions, the first and most obvious being whether one can in fact teach it to others. That this is possible is what Socrates immediately goes on to question, and Protagoras' answer to this question, and the resulting discussion of the relation between the virtues, take up the remainder of the dialogue. There is,

${ }^{13}$ The phrasing "poein andras agathous politas" is ambiguous: Denyer $(2008,96)$ follows some commentators in saying that the words "andras agathous politas" form a single expression and that the phrasing accordingly does not mean "to make men good citizens", but rather to produce good citizens (men), since this seems to be what the phrase means in e.g. Aristophanes' Knights 1304. Syntactically, however, nothing speaks against reading the phrasing as containing a double accusative, as other commentators have construed it, in which case it could mean either "to make men good citizens" or "to make good men citizens". I owe this observation to Hayden Ausland.

${ }^{14}$ That Aristotle suggests that some sophists thought that political expertise is identical with rhetoric (EN 1181a14-15) does not guarantee that Protagoras was of this opinion.

${ }^{15}$ See Friedländer (1964, 5 and 7). Hans-Georg Gadamer suggests that euboulia was a "politisches Losungswort der damals neuen Paideia" (Gadamer 1991, 147). 
however, another question, perhaps less explicit, but more crucial: what does Protagoras understand by being well-advised? Protagoras' view becomes clear only gradually, as Socrates forces Protagoras to reveal his thoughts on this question. When Socrates raises the question how Protagoras understands the virtues in relation to each other, it is also in order to reveal Protagoras' understanding of the political art he claims to teach.

Here we will limit ourselves to looking at a number of passages where Protagoras' mathema, his teaching, is touched upon, if not directly revealed, more specifically at a number of passages prior to what we may call the crisis in the dialogue that erupts at $334 \mathrm{c} 8$ and threatens to end the conversation between Socrates and Protagoras. This way of proceeding is necessitated by the fact that Protagoras never explicitly states what euboulia or the political craft is. Protagoras and Socrates seem to discuss whether teaching what Protagoras claims to teach is possible without ever really clarifying what it is Protagoras teaches. It is, moreover, conspicuous that, while the discussion with Hippocrates emphasizes the soul and the importance of understanding that by which souls are nourished, Socrates' long discussion with Protagoras never addresses the question what soul is, or, for that matter, what virtue and psychic nourishment are. ${ }^{16}$ This may suggest that Protagoras is not particularly interested in these questions, although we should note he does claim that courage arises from nature and good nurture for souls (351b2-3), which may suggest that he sees himself as offering for sale the nurture needed in order that a good natured soul should become truly courageous: perhaps he simply does not get a chance to expound his own views on these matters because Socrates refutes him every time he tries to say something.

That the answer to the question in what Protagoras' own teaching consists is left frustratingly vague is particularly clear from the speech Protagoras gives in order to demonstrate that political craft, presumably identical with euboulia, is something that can be taught. As has been noticed by many commentators, Protagoras' speech is filled with riddles or apparent inconsistencies with what Protagoras as a sophist actually does.

The speech emphasizes that everyone needs to participate in political virtue since the polis could not come into being if people had no share in reverence and justice; therefore, the mythical part of the speech asserts, Zeus distributes political virtue or knowledge to everyone, in contrast to the specialized crafts given to men by Prometheus (322c5-d6). This assertion seems to correspond to the claim in the argumentative section of the speech that everyone, from the wet nurse to the lawgiver, teaches virtue to everyone else (325c5-326e4). We note that this latter claim to a certain degree corresponds to what Anytus and Meletus, two defenders of democracy, say about the ability to make people better in the Meno (92e3-6) and Socrates' defense speech (24d11-25a11), respectively, namely that all true gentlemen are able to make others better. But even if Protagoras' claims about the teachability of virtue may thus make him more palatable to democratic minded

${ }^{16}$ See Morgan $(2000,151)$; see also Benardete $(2000,196)$ who suggests that the "Gorgias examines the soul-structure of the Republic apart from the city, and theprotagoras examines the citystructure of the Republic apart from the soul." 
Athenians, as has been suggested by A. W. H. Adkins, ${ }^{17}$ it leaves Protagoras with some serious problems. If Zeus distributes political knowledge to everyone, no teaching is needed, and hence Protagoras is out of business. If this is only a myth meant to point out that everybody has a potential for becoming virtuous, if Protagoras' serious claim is that everybody teaches virtue to everyone else, culminating in the good lawgivers who lay down the laws of the city as paradigms in accordance with which everyone is forced to live (see 326c6-d7), Anytos' and Meletus' objections to sophistry in general would still hold: it is the gentlemen in the city, or the laws established by the good old lawgivers, not professional teachers, that make the young better. Finally, Protagoras' speech only discusses three virtues, namely justice, sound-mindedness and piety. ${ }^{18}$ Even if it should be true that everyone needs to participate in these virtues to some extent for the polis to exist, none of them seems to be identical with what Protagoras claims to teach, euboulia, or with what young ambitious men are interested in learning. ${ }^{19}$ Put differently, the three virtues may indeed be political virtues, but they can hardly be the same as the political craft of being well-advised Protagoras advertises as his mathêma.

In his lecture-course on the Protagoras, Leo Strauss suggests that it is the fact that Protagoras leaves out the political virtue he himself claims to be able to teach from his speech on the teachability of political virtue that is ultimately the reason Socrates wishes to enquire into the unity of virtue. ${ }^{20}$ Is the expertise of the politically powerful man (anêr), the knowledge Protagoras presumably claims to be able to teach, really identical with the political virtues in which Protagoras claims that not only men, but women and children must share (325a5-6)? On the surface the discussion about the unity of virtue that follows upon Protagoras' speech is motivated simply by the fact that Protagoras himself speaks of justice, sound-mindedness and piety as a unity in his speech (see in particular 324d6-325a2). But from the beginning of this discussion, where Protagoras suggests that the virtues enumerated in his speech are a unity only in the sense that they are parts of virtue (329d3-4), it becomes clear that Protagoras has failed to mention the two virtues he regards as the most important, courage and wisdom, in his speech. It also becomes clear that he thinks that one can have courage without justice and justice without wisdom (329e6-330a3). If one is allowed to regard justice as a stand-in for the three virtues

\footnotetext{
${ }^{17}$ Adkins (1973, 9-10). Leo Strauss likewise suggests that Protagoras seems to deliberately conceal what he is teaching as a result of his caution (Strauss 1971, lecture 9,7-15 and compare with lecture 6, 22-23). Friedländer $(1964,13)$ observes that Protagoras' apparent inability to distinguish himself from other teachers of virtue results from the fact that "jeder absolute, jeder geistige Maßtab dem Protagoras fehlt."

${ }^{18}$ The speech begins by mentioning only aidôs and dikê as the gifts of Zeus at 322c3, they are then replaced with dikaiosunê and sôphrosunê at 323al-2 and at 325al the political virtues are listed as dikaiosunê, sôphrosunê and to hosion.

${ }^{19}$ Coby $(1987,46)$ states that "Protagoras' own sophistry is compatible with freedom because he teaches his students the subjects they naturally desire. And because his students are at the beginning of their adult careers, what they desire is instruction in the craft of success - how to succeed politically and economically". See also Weiss (2006, 33).

${ }^{20}$ Strauss $(1971$, lecture 9, 23-24). See also Weiss $(2006,38)$.
} 
that are mentioned in the speech, Protagoras seems to say that courage may be at odds with the virtues required for the existence of the polis, whereas the possession of the latter, i.e. justice, does not necessarily mean that one is wise. Perhaps this is also why he later (351b2-3) insists that courage requires a good nature as well as nurture, as mentioned above. The sophist will help give the nourishment real men need in order to become truly courageous, a kind of courage that stands in potential conflict with the political virtue possessed by ordinary citizens.

That Protagoras in fact believes that wisdom, in the sense of being well-advised, is in potential conflict with the virtues required for the city to exist, is suggested from the discussion of the relation between wisdom and sound-mindedness that begins at $332 \mathrm{a} 2$ and carries over into the discussion of the relation between soundmindedness and justice beginning at 333b7. The steps of this discussion are, in short, as follows: Socrates gets Protagoras to agree that the opposite of aphrosunê, lack of good sense, is sophia, wisdom, and further gets him to accept that sôphrosunê, sound-mindedness, is the opposite of aphrosunê as well. Socrates then goes on to suggest that one thing can have one opposite only, to which Protagoras agrees $(332 \mathrm{c} 6-\mathrm{d} 3)$. This leads to the conclusion that wisdom and sound-mindedness are identical (333b5-6).

Socrates next asks whether Protagoras believes that one who is sound of mind can do unjust things (333b7-c1). Protagoras claims that he would be ashamed to agree with this - which of course by no means implies that he does not in fact agree - but he admits that many people say so $(333 \mathrm{c} 2-3)$. When Socrates then asks Protagoras whether he would prefer that Socrates conduct his conversation with these people or with him, Protagoras opts for the first and suggests that Socrates should discuss this account given by "most people" (hoi polloi, 333c5-6); Protagoras thus cleverly moves from asserting that he would be ashamed to admit what many people say to the claim that the view that one can act unjustly while being of sound mind is in fact the account of the matter most people give. We should note that he does not necessarily imply that most people admit this openly; his previous speech in fact suggests that Protagoras is well aware that most people would not (cf.323a5c1). ${ }^{21}$ This maneuver leads to a short imaginary dialogue with these many, where Protagoras is induced to answer on their behalf. The steps of this little dialogue are as follows. It is accepted as a premise that people can be sound-minded while acting unjustly (333d4-6). But does not Protagoras say that being sound-minded is the same as using good sense (eu phronein), Socrates asks. Protagoras agrees that it is. He also agrees that using good sense, when it comes to doing unjust acts, is the same as being well advised (333d7-10). He finally accepts that one is sound-minded or well-advised when committing unjust acts if one fares well while doing so, rather than if one does not (333d11-12).

Although these concessions are made by Protagoras while speaking on behalf of those who are unashamed to admit that one can be of sound mind while acting unjustly, we note that Socrates, within this dialogue, subsequently addresses Protagoras in the second person singular (cf. $333 \mathrm{~d} 3, \mathrm{~d} 4, \mathrm{~d} 5, \mathrm{~d} 8$ ): this suggests that

${ }^{21}$ Denyer's observation $(2008,132-133)$, that "in spite of what Ppotagoras says here, it is hard to find many, or even any, who said outright that one can be temperate in committing an injustice. Popular opinion held the opposite ..." may thus be beside the point. 
he is not fooled by Protagoras' strategy. We also note that Socrates, although he previously was very reluctant to let Protagoras state anything but what he himself actually thought (331c5-d2), now appears much less insistent: it doesn't matter to Socrates whether it seems to Protagoras that one can act unjustly while being sound minded, since it is the logos that Socrates wants to test (333c7-9). He adds, however, that it may perhaps happen that both the questioner and the answerer will be tested or examined (sumbainei ... exetazesthai) as well. And this in fact seems to be what happens: Socrates in practice assumes that the logos Protagoras is ashamed of admitting and therefore ascribes to "many others" is in fact Protagoras' own logos, and the discussion of the logos is thereby also an examination of Protagoras.

So let us assume that Socrates has seen through Protagoras' attempt at keeping up appearances. What, then, is the upshot of Socrates' inquiry into the relation between wisdom and being of sound mind? Since Socrates has already established, if on rather shaky foundations, that piety and justice are the same or at least almost the same (333b5-6), it is easy enough to assume that he is now attempting to show that sound-mindedness and wisdom are also identical, in order to argue that all the virtues are identical. As Roslyn Weiss points out, the first step would be to show that doing injustice "issues in bad things, that is, in things that are harmful to human beings", which contradicts the claim that being well advised or wise "issues in good things"; but this step is never taken since the argument, according to Weiss, is "cut short by a Protagorean tirade" (beginning at 333e1). ${ }^{22}$ This interpretation seems reasonable in light of Socrates' strategy for the rest of the dialogue. But here we are not concerned with the rest of the dialogue as designed by Plato, but only with what Protagoras has admitted so far within its dialectical drama. And the fact is that until now, Protagoras has admitted the following: wisdom is identical with soundmindedness, and sound-mindedness is identical with using good sense, which again is identical with being well advised, the mathêma that Protagoras explicitly claims to teach. Furthermore, since Protagoras admits that one can be of sound mind while committing injustice, being well advised is potentially in conflict with justice. As justice is apparently identical with piety, being well-advised must also be in potential conflict with piety. At this point in the dialogue, rather than having a unity of virtue, we then seem to have two sets of virtue, piety and justice, on the one hand, the main virtues treated of in Protagoras' speech, and wisdom and sound-mindedness, which now appear identical with being well-advised, on the other.

This seems to suggest that Protagoras draws a distinction between political virtues (cf. 323a6-7) that depend upon self-constraint meant for the common run of people, virtues that are necessary for the survival of the polis, and higher or more manly virtues connected with the intellect, which help a real man or at least a clever one maneuver deftly, and perhaps unjustly, within the polis in order to secure his own gain. In this connection we may note that, while sound-mindedness (sôphrosunê) was mentioned in Protagoras' speech as one of the necessary political virtues alongside piety and justice, it had a rather peculiar status: whereas everyone, according to the speech (323a5-c1), believes that it is sound-minded to tell the truth in the

\footnotetext{
${ }^{22}$ Weiss $(2006,40-41)$.
} 
case where one lacks an ordinary craft, when it comes to justice people believe such a conduct would be madness (mania). As madness is commonly regarded as the opposite of sound-mindedness, Protagoras seems to suggest that when it comes to justice, one is sound-minded if one manages to keep up the appearance of justice, even when one is not just. Rather than treating sôphrosunê as an ability to control one's desires, as one might expect Protagoras would do when emphasizing the importance of virtue for the existence of the polis, Protagoras gives this virtue a decidedly "intellectual" interpretation that points away from self-control to the more "manly" virtues of being clever, wise and well-advised.

The full implications of Protagoras' identification of sound-mindedness and wisdom with being well advised only become clear in the sequel to this discussion, in particular from the discussion of the measuring art. We cannot look into that here. Instead, we will end by looking briefly at what Protagoras has to say about the good in the passage 333d13-334c6, since this seems to be the aim for the mathêma of euboulia. Protagoras has admitted that one does well while committing injustice if one is well advised, and this leads Socrates to ask whether Protagoras believes that some things are good (333d13). Protagoras answers affirmatively. When Socrates then asks him whether he agrees that good things are the things that are beneficial (ôphelima) to humans, Protagoras swears that he also calls some things good even if they are not useful to humans (333e1-2). He explains this curious remark by elaborating at some length how "multi-colored (poikilon) and manifold (pantopadon) a thing the good is" (334b6): what is beneficial to plants is not beneficial to animals, what is beneficial to the outside of the body is not beneficial to the inside and so on. To put it briefly: the good, which is identical with the beneficial, is relative to different kinds of living beings, according to Protagoras, since what is good for one is bad for another. We may wonder whether he also believes that what is beneficial to one polis is not beneficial to another, that what is beneficial to the polis may not be beneficial to man and, finally, that what is beneficial to one man is perhaps not beneficial to another. If this is indeed his view, Protagoras' mathêma, euboulia, which is directed at the good, seems to be grounded in another mathêma, another doctrine, namely a doctrine about the good and the beneficial.

Let us then conclude with some thoughts about Socrates, Hippocrates and Protagoras. We have seen that Hippocrates first and foremost wished to associate with Protagoras in order to become clever at speaking. If he believes that this is all it takes to become renowned in the polis, it is to some degree in keeping with Athenian practice as depicted by Socrates. There is no specific expertise regarding political matters, everyone is in principle as competent as any other. Protagoras, on the other hand, seems to suggest that this is not true - there is a specifically political craft, namely euboulia, which makes one a more capable citizen than others who lack this craft. At the surface, this may look rather Socratic: at least according to a standard view, Socrates criticizes democratically ruled societies because they do not acknowledge that real understanding of political matters is needed in order rule society. In the Republic, Socrates calls this understanding wisdom and claims it is directed at the good. He also states that this wisdom makes the polis as a whole well advised (428b4-d9, 504e3-505b3). But this is also where-Protagoras and Socrates 
might seem to part ways. Protagoras claims that the good is what is useful, and the useful is relative to us, whereas the Socrates we find in the Republic, at least, suggests that the good is something in itself, independent of what we think about it. This doctrine is never mentioned by Socrates in the Protagoras, but Socrates' ostensible purpose in the dialogue is not to bring his own view on such matters into the open, but rather to bring Protagoras' views to light for the benefit of Hippocrates. Whereas Socrates began by tending Hippocrates like a physician of souls by first assessing the quality of his soul and then demonstrating to him that he did not know what sophistry is, we may suggest that Socrates in his long discussion with Protagoras in fact evaluates the quality of the wares Protagoras offers for sale by bringing them into the open.

And what Socrates seems to have brought to light is that what Protagoras offers under the fine-sounding name of being well-advised is simply an ability to calculate how things will be best for oneself, without specific concern for the ways in which they may be better for others. Should Hippocrates assimilate this mathêma it would turn him in the direction of tyranny on a small scale, at least in so far as he will become more capable of using the polis simply with a view to his own advantage. If so, there is indeed good reason to be afraid of what Protagoras offers for sale, in regard to the souls of the young men seeking to become distinguished by associating with him. We should note that the problem is not that he claims to be able to teach a political art, the knowledge of being well advised that makes men good citizens. If he really was able to teach this, it would a most noble thing (319a7); the problem is rather that his teaching is noble in name only, whereas the reality seems to be that it consists in nothing but the ability to calculate how one should have the greatest advantage, quite possibly at the expense of others. It is thus hardly a surprise that Protagoras is sympathetic to Socrates' later suggestion that the salvation of our lives (tis sôteria ... tou biou; 356d3) is an art of measurement that will help us calculate what is pleasant and what is not, in order that we may fare well (eu prattein; 356d1) by acquiring more pleasures and fewer pains (see 355e5-356e4). It is quite doubtful that such a teaching will help any soul thrive, at least not if we accept what Socrates suggests in the Republic, that justice is the heath of the soul (Rep. 444c1-e3). Protagoras' mathêma is indeed dangerous and Socrates' initial warning was therefore not unfounded.

Whether Hippocrates too realizes the danger of Protagoras after he has overheard Socrates' discussion with Protagoras is another question. Can Socrates with certainty be said to have removed Hippocrates' infatuation with Protagoras through his discussion? One could argue that Socrates, by beating Protagoras in the give and take of dialectical question and answer, has at least demonstrated to Hippocrates that if he wishes to become clever at speaking, he should rather stay with Socrates, like Alcibiades. One could further argue that Socrates, through his ability to bring the consequences of Protagoras' teachings into the open, against Protagoras' will and perhaps even without Protagoras' knowing what it is that is brought into the open - demonstrates that the mathêma that Protagoras offers for sale will not prove palatable to Hippocrates in the end. As the discussion of the art of measurement seems to suggest, Socrates ends up forcing Protagoras to admit that euboulia is nothing but prudential forethought that will allow one to avoid risk and calculate 
how best to achieve pleasure. This admission may prove to Hippocrates that he will not get what he wants from Protagoras. Hippocrates wishes to become distinguished in the polis, presumably in the manner that Pericles is, namely as a great political speaker. If we can trust Aristotle, what drives people with political ambition is only at first sight their desire for honor and, and upon closer inspection their desire to be honored for virtue (EN 1095b22-30). But on the reading offered here there is nothing noble in what Protagoras teaches and hence no honor to be gained through practicing it. This much may indeed have become clear to Hippocrates, even if the finer points of Socrates' arguments may have for the time being escaped him. And if Hippocrates is indeed as spirited as Socrates' initial description suggests, we have good reason to suppose that he will make sure to chase Socrates down later to ask him to explain what exactly these arguments were.

Acknowledgments I wish to thank Hayden Ausland, Vivil Valvik Haraldsen and Kristin Sampson for reading earlier versions of the paper; they all contributed with many fruitful suggestions that improved the final manuscript. The present work was written as part of a postdoctoral research project financially supported by the Danish Council for Independent Research.

\section{References}

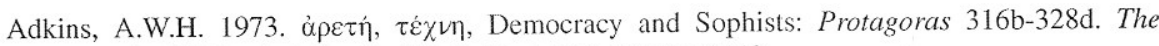
Journal of Hellenistic Studies 93: 3-12. doi:10.2307/631448.

Benardete, Seth. 2000. Protagoras's Myth and Logos. In The Argument and the Action - Essays on Greek Poetry and Philosophy, ed. Ronna Burger and Michael Davis, 186-197. Chicago: The University of Chicago Press.

Coby, Patrick. 1987. Socrates and the Sophistic Enlightenment. Cranbury: Associated University Press.

Denyer, Nicholas. 2008. Plato's Protagoras. Cambridge: Cambridge University Press.

Friedländer, Paul. 1964. Platon - Band II, Die Platonischen Schriften, Erste Periode. Berlin: Walter de Gruyter \& Co.

Gadamer, Hans-Georg. 1991. Der Idee des Guten zwischen Platon und Aristoteles. In Gesammelte Werke 7 - Griechische Philosophie III, 128-227. Tübingen: J. C. B. Mohr.

Lampert, Laurence. 2013. How Philosophy Became Socratic. Chicago: Chicago University Press.

Manuwald, Bernd. 2006. Platon Protagoras. Introduction, Translation and Commentary. Göttingen: Vandenhoeck \& Ruprecht.

Moes, Mark. 2000. Plato's Dialogue Form and the Care of the Soul. New York: Peter Lang.

Morgan, Kathryn. 2000. Myth \& Philosophy - From the Presocratics to Plato. Cambridge: Cambridge University Press.

Roochnik, David. 1996. Of Art and Wisdom. University Park: The Pensylvania State University Press.

Stokes, Michael C. 1986. Plato's Socratic Conversations - Drama and Dialectic in Three Dialogues. London: The Athlone Press.

Strauss, Leo. 1971. Plato's Protagoras. A Course Given in the Spring Quarter 1965 at the Department of Political Science, Chicago. The references are to an unofficial transcript of recordings from the seminar, http://leostrausscenter.uchicago.edu/course/plato-protagorasspring-quarter-1965. Accessed 19 May 2016.

Weiss, Roslyn. 2006. The Socratic Paradox and Its Enemies. Chicago: The University of Chicago Press. 